\title{
Chapter 16 \\ The Loss of Deontology on the Road to Apathy: Examples of Homelessness and IVF Now, with Disaster to Follow
}

\author{
Veselin Mitrović and Naomi Zack
}

\begin{abstract}
Vulnerable groups, from contemporary homeless people to IVF embryos may fall between the cracks of otherwise good social values, such as government welfare programs and individual autonomy. These present and slow disasters are in principle no different from more immediate catastrophes resulting from natural events or wars that harm civilians. The failure to respond with indignation and demands for change constitutes apathy, which is also an absence of deontology. We begin with concrete examples of social apathy, in Part 1. Our examples are homelessness and IVF, neither of which are usually considered disasters but both of which are in fact ongoing disasters within normal society. Part 2. is a discussion of theoretical and practical deontology that is lacking in these examples.
\end{abstract}

Keywords Vulnerability $\cdot$ Social values $\cdot$ Resilience $\cdot$ Homelessness $\cdot$ In vitro fertilization $(\mathrm{IVF}) \cdot$ Deontology $\cdot$ Apathy

\subsection{Introduction}

Vulnerable groups, from contemporary homeless people to IVF embryos may fall between the cracks of otherwise good social values, such as government welfare programs and individual autonomy. These present and slow disasters are in principle no different from more immediate catastrophes resulting from natural events or wars that harm civilians. The failure to respond with indignation and demands for change constitutes apathy, which is also an absence of deontology. We begin with concrete examples of social apathy, in Part I. Our examples are homelessness and IVF, neither of which are usually considered disasters but both of which are in fact

\footnotetext{
V. Mitrović $(\square)$

Faculty of Philosophy, University of Belgrade, Belgrade, Serbia

N. Zack

Philosophy Department, University of Oregon, Eugene, OR, USA

e-mail:nzack@uoregon.edu
} 
ongoing disasters within normal society. Part II is a discussion of theoretical and practical deontology that is lacking in these examples.

\subsection{Part 1: Homelessness and IVF Sacrifice}

We present two case studies. The first paints a picture of social apathy and loss of care through social and linguistic transformation of one of the most at risk and nonresilient social groups: the homeless. "Resilience is understood as the capacity to act voluntarily in the interest of enhancing one's own life conditions (e.g. anticipation and capacity for planning)" (Mitrović 2015a, b, 187). When resilience is lacking within a group in society, or by society at large in interacting with that group, the group's vulnerability increases.

Our second case study derives from one personal story of ten former patients of an IVF (in vitro fertilization) procedure. The subjects in this study possessed a strong will for having offspring. Apathy and the loss of care on a broader social and institutional level, combined with the desire for offspring at any cost, forces the clinical subjects who want to become parents to disavow their own freedom, ultimately rendering them more apathetic than they would otherwise be. Gradually, these actors cross from a group with some prospects into the non-resilient group. In other words, these individuals consider that the state/institutions can compensate for the lack of altruism and solidarity. Altruism is here understood as CD Batson defined it, a "motivational state with the ultimate goal of increasing another's welfare" (Batson 2011, 20). With that in mind, solidarity as a social value could be taken to be "a degree of altruism in competitive social systems, e.g., mutual support in social reproduction, providing basic rights, social protection, and concern throughout the main channels of social mobility in a given community" (Mitrović 2016, 49). Both the prospective parents and their sacrificed embryos are examples of disaster victims. The parents are victims of moral disaster, the sacrificed embryos of loss of life.

The premise of these case studies is that the transformation of solidarity into state altruism leads individuals and groups to think that they cannot help themselves or others in need, even their close family members whose lives might be in their hands. In catastrophic situations, this state of affairs would mean greater susceptibility to risk, in addition to rendering rescue operations more difficult.

Both of our case studies include a personal view of the sovereign or good life. What kind of autonomy represents the true internal choice of actors, informed by the idea one has of the good life? This question is of particular importance in borderline cases, as well as for the prevention of eugenic choices when making decisions regarding the lives of others (especially the marginalized) in the course of catastrophes. 


\subsection{Case $1^{1}$ : How the Clochards Became the Homeless}

The total number of individuals in Serbia today who have plans to enhance their life conditions in the coming 1-2 years is $50.3 \%$. In this study, we call them people with non-damaged resilience. In contrast, $49.7 \%$ of the population (non-resilient) has no such life plans (Mitrović 2015a, b). ${ }^{2}$

One group of people belonging to the non-resilient are the homeless. The word "homeless" as it is used today did not exist in the social vocabulary of Yugoslavia. In a small town in north-eastern Bosnia (when Bosnia and Herzegovina was one of the six federal republics in Yugoslavia) where one of the authors (Mitrović) grew up in the 1970s, there were two persons who could vaguely be seen as klošar. The official terminology of the time termed these persons "socially endangered," but they were colloquially known as klošar, that is, hobos.

The Serbian klošar comes from French clochard, meaning a person who limps, an etymology relevant for this article. To call one "a hobo" had a bohemian, almost sympathetic sound. However, what exactly is the background of the word "hobo"? As "Hobo" means poor, alcoholic, artistic soul, lacking permanent residence. But on top of this, a hobo is either physically or socially "lame" or "limping." Were such persons born "lame" or did they become part of the "lame" (hobo) social group, on an individual basis or simply through social assignment? How does one become recognized as a "lame, marginalized" person? In order to answer these questions, we will have to look beyond the veil of personal and collective memory to a country that held promise, yet is now dead.

The two men known in the small town in the 1970s did have homes, usually provided by the community, although they were unemployed. One of them sold candy apples in the yard of a local elementary school. The other of the two "marginals" worked as a seasonal laborer. Regardless of their meager incomes, consisting in part of occasional jobs and small scale trading, and in part their social benefits, the local office for social protection ensured basic material means of subsistence for these men and their families. Part of their social welfare was free healthcare and treatment, as was the norm and legally guaranteed practice for all citizens.

One of the basic social values in the socialist system was solidarity. In addition to the state policy of free education and social and health protection, solidarity was, in one way or another, the basis of communal life. In that sense, these two men were part of the community, while also leading independent lives. They took advantage

\footnotetext{
${ }^{1}$ This case study is a shortened and adapted version of an article by Veselin Mitrović (2015a). How Klošar Became the Homeless Upon the Dissolution of Yugoslavia. Homelessness and Home, Community Philosophy Institute, Philosophy Department, University of Oregon. http://homelessness.philosophy.uoregon.edu/narratives-of-homelessness/ Accessed 24 July, 2016.

${ }^{2}$ The presented data are from Mitrović's research of apathy in Serbian society, published in cited reference. This research is done in the frame of the wider scientific project "The Challenges of the New Social Integration: Concepts and Agents." (nr.179035) granted by the Serbian Ministry of Education, Science and Technological Development.
} 
of their right to basic material necessities: a roof over their heads, minimum income, healthcare and education for their children, and so forth.

A homeless person, in the social and linguistic sense, assumed relevance in the last decade of the twentieth century, during the painful and bitter dissolution of socialist Yugoslavia. Quickly, if unoriginally, politicians, along with a section of the intellectual elite, coined a term for these people: losers of the post-socialist transition. While deeply opposed to a term that characterizes individuals and groups as "losers" at a given historical moment, we find citing this phrase an apt way to present the reader with a picture that society (or the majority) can form of someone who has lost everything but his or her life. The tragic loss of basic civil rights, not to mention the overnight disappearance of guaranteed benefits, was justified by way of a new "loser or winner ethics" due to some evolutionary, well-nigh eugenic, understanding of the incompatibility of some individuals and groups to a specific social programme. It was as if the power of culture and yesterday's basic values, such as solidarity and tolerance, completely disappeared with the dissolution of a way of life, wiping out a promised better future in the (nearly) ethnically clean former Yugoslav republics. In the course of the wars at the end of the twentieth century, the region of the west Balkans faced hundreds of thousands of refugees. They became homeless, even though they were now placed in collective centers, ghettoized from the rest of the "domestic" population. Thus the social and political transformation, begun in the late eighties, and the wars of independence in the nineties, created fertile ground for homelessness in the contemporary sense of the word.

What happened to the old, exotic image of the hobo? Did he disappear or has the homeless person (who is one of the losers of the transition) acquired one of the hobo's faces, the socially "lame" person? How, we might ask, does one today become a hobo or a socially "lame" person in this region?

Complementing the sketch above of the hobo from the 1970s, before the breakdown of socialist Yugoslavia, we offer a specific example of Belgrade homelessness to describe what homelessness means today. After a domestic tragedy, such as a violent breakup of a family, an average member of the middle class ends up in prison where he may spend a third of his life. He has lost his house, family, and, of course, his employment, the guarantor of middle class status. After a while, he ends up on the street, in the city center, near the place of work of his son, who has practically grown up without either parent. He can be seen today, three sheets to the wind, slumped on the pavement in front of the offices of the most important Serbian daily, Politika, and the building of Radio Belgrade. More than one journalist, on more than one occasion, has tried, and some have even succeeded, in coaxing out of him his story and explanation of homelessness (se non è vero, è ben trovato - even if not true, it is well conceived). He told them that by choosing a life in the open, imbibing copious amounts of alcohol, he has chosen a sort of slow death. One particularly cold winter, he loses several toes and is left literally limping. He becomes recognizable socially and medically as lame, homeless, alcoholic, an ex-con, etcetera. Even so, some of his acquaintances still bring him warm meals and others even alcoholic beverages in front of Politika's offices. Obviously, certain people still regard him as a member of the community and accept his self-identification as a homeless person 
who is not seeking to survive in the long run, but rather dissipate his life towards a slow death.

A few years later, Belgrade gets a homeless shelter, which usually happens to be full in the winter months. On several significant occasions at the shelter, this homeless man attempts to die his slow death. He looks quite old and weak, but is protected (nolens volens) in the cold winter months. The institutionalization of homelessness that occurred with the social changes that followed the dissolution of socialism not only limited the way of life, but also the way in which a homeless person wished to die. In post-socialist, post-bellum circumstances, the poor socioeconomic conditions of life, combined with individual acts of protection, could create an image of a "caring" or "altruistic" society, one that cares about its members, regardless of their social status. However, the basic social value of solidarity seems to have vanished along with the old political system and former state, leaving behind a vacuum to be filled by the invisible hand of state altruism. In other words, what was once a matter of right is now a matter of government charity. What lurks beneath the image of an altruistic society? Is there a dark side to the "altruism" that regulates not only the way of life but also the way of death?

Social history and psychology remind us of the possibility of measuring authoritarian behavior. Government policy that removes the homeless from the streets and eyes of the majority, regardless of altruistic explanations, can be valued as a caring activity in poor European countries, where around half the population possesses no short term plans for improvement of their life conditions. However, strict regulation that at first sight may appear altruistic can be easily upended into a totalitarian type of ordering the daily life of citizens, regardless of whether they do or do not have a roof over their heads.

There is a thin line between sympathy with government policy that prohibits one's ways of living and dying, and cultural complicity with the state determining who lives and dies. The social and linguistic metamorphosis of the erstwhile Yugoslav hobo into a homeless person could be a social bellwether for much wider future socioeconomic and political change in this area of the world. The collapse of an old ossified political system, taking place in the midst of the creation and harmonization of European Union regulation, also transforms former social and health security into a new type of "altruism." Yet does such altruism carry more worry for the most precarious social groups? The answer to that question depends on the balance between the way in which, on the one hand, the majority sees its rights and achievements, and, on the other, the sympathy with the actions of government altruism that influences the lives of the homeless and other marginalized groups. In other words, the answer is in the sociological imagination of today's "altruism" in the most developed countries.

Social sympathies with some limits on how members of marginal groups will die, open not only the possibilities that the majority or the state decides who and when someone will die - above all the marginalized - but also the further step of social and ethical justification of measures that allow the majority its inertness and apathy in a situation that requires taking action. 


\subsection{Case $2^{3}$ : False Autonomy. The Story of Participant P8: How Good a Mother Can I Be?}

The Serbian health care system provides the possibility of free treatment for infertility, recognized as an illness, allowing for the fulfillment of the social role of parenthood. The system ensures medical, legal, and social conditions for conception through Assisted Reproductive Technology (ART) for partners and single women with diagnosed infertility. From this perspective, altruism refers to one organism enhancing the reproductive advantage of another, especially at a cost to itself. This poses the question of "whether the state can personify a characteristic such as reproductive or procreative altruism" (Mitrović 2016, 49).

The fact that institutions in Serbia did not have a bio-repository is one of the most frequent elements that fuels dilemmas regarding the patient-physician relationship. The most frequent response shows how this situation induces potential misunderstandings in medical treatments. According to Participant P8, "Through hyperstimulation I had 30 healthy eggs. So, I had to ask myself what happened with them, because I didn't freeze my eggs, so where are they?" Given that egg preservation was not possible in Serbia until recently, the patient never asked outright what really happened with her eggs. Participant P8 is a highly educated woman, in her late 30s, married, fully employed, and an atheist. She showed complete unwillingness to accept or donate generative cells or embryo for any purpose whatever. "I didn't use donated eggs or semen, nor would I, because I want to know who the father of my child is, and at the same time, I want to be the biological mother of that infant. Of course, objectively, that is not important when the child grows up" (P8).

Participant P8 would agree to the possible donation of her husband's semen, adding, however, that it would be physiologically "not easily acceptable for the purposes of donation" (P8). She chose to undergo in vitro fertilization at a private clinic, outside the government run health care system, for better expediency due to her age. After examining the rules for the free infertility program, the participant P8 decided to bypass "the paperwork": "I saw on the internet how much paperwork we needed for free in vitro... I knew that this was impossible if one works from 9 to 6" (P8).

Participant P8 and her husband were never asked what they wished to do with the remaining ovum/semen cells or embryos in Serbian private hospitals. All participants agreed that regardless of the health or normal development of these cells or embryos, patients should be asked about their fate. Further, like nearly all the other participants, P8 wished to preserve her own embryos, even if it meant preserving embryos with irregular cellular differentiation.

In addition to the difficulties of conception, this story is characterized by the use of medical technologies to control the number of children and the time of their birth. Participant P8 had a pregnancy terminated a few years prior to her decision to

\footnotetext{
${ }^{3}$ This portion of the article is an adapted version of an article by Veselin Mitrović (2014). Procreative Ethics of Care in the Process of IVF in Serbia: A Culture of Giving or a Crisis of Altruism? Teme 1: 193-211 (Serbian).
} 
undergo IVF. The termination was motivated by the fact that she had become pregnant with a different man. Her general attitude towards termination was positive, because she could choose the man with whom to have a child. After obtaining one child through in vitro fertilization, she was asked how many embryos had been returned to her and whether the number of children was her choice. The answer was that the doctors reached the legal maximum and in order to increase her chances of conception returned three embryos. However, none of the doctors asked her nor informed her regarding this number during the course of the procedure. Regarding this, she responded: "I think that it is not necessary to know everything about these procedures, because the doctor is the specialist and he knows what he should do" (P8).

During Participant P8's early pregnancy, one of three embryos in the womb did not continue to differentiate (which is not uncommon), while the other two developed normally. In the interest of her view of the good life, participant P8 chose to remove one of the remaining healthy embryos, that is, to perform an embryo reduction. She explained her decision briefly, by saying that she knows herself: "I decided on my own because I know myself. After a few weeks of thinking about twins, I realized that I am not capable of carrying this through properly and that I could deal with one child, but not two. I know that I will need help and I do not have it. Given how I am, one child is what I can do" (P8).

When asked whether she regards embryo reduction as an abortion, she answered affirmatively. She was further asked whether she did this because she was afraid that a twin pregnancy could cause premature delivery. The answer was similar to the previous one: "Yes, I was afraid of that too, and in the end it turned out that had I not done so, I would not have had any children! But I couldn't have known that at the time. I decided based only on knowing myself" (P8). Interestingly, P8's husband was in favor of adopting a child, which she absolutely opposed. The reason, much like her previous position, lay precisely in connecting aspects of her personality with her idea of a good life. Here is how she describes this connection: "I know myself, and I know my relation towards others' children, children that are not mine. So I was convinced that I would not manage that properly" (P8).

This example shows how an ideal understanding of the role and motivation of parenthood may contrast with an idea of a good life. In particular, it seems that the responsible and autonomous aspect of the mother's identity are emphasized. That is, by controlling biotechnological activity, the mother also entirely controls the idea of the good life. P8 would in that regard be prepared to resort to genetic engineering to enhance the capacity of the child: "If possible, I would enhance the intelligence of the children through genetic engineering; why be stupid if it can be smart" (P8).

Yet given such a clear idea of personhood and the good life, what remains unclear is P8's unwillingness to bring about the good life of other persons in a similar situation. Of course, with the limit of research assumptions, this article can do no more than suppose that the potential incongruence in the ethics of care lies precisely in that portion of the individual that characterizes the self. This aspect of personality in this case is understood in its most narrow sense. It is in direct connection with the idea of the good life of the parent - the feeling of self-actualization through birthing, 
regardless of the origin of generative cells. Another detail from the case study testifies to this narrow view of the self. Participant P8 offered one of the most interesting affirmative answers to the question whether participants would genetically determine their child to be an altruist. Despite choosing altruism for her child, P8 particularly emphasized that she would never choose that for herself, on the contrary. Therefore, we could conclude that her insecurity regarding her role as a parent within the idea of the good life lies in a narrowly understood selfhood. Although the autonomous aspect of identity is emphasized in this case study through the decisive and different actions of control of having a child, the truth may in fact be completely different.

Everyone is free to control their procreative potentials in seeking the good life. However, the analysis also shows that that responsibility is understood as a kind of prohibition in procreation of using anything that does not biologically come from one's partner, as well as oneself. Such an idea of responsibility has a much broader reflection on the type of genetic altruism already mentioned.

Participant P8's readiness to genetically determine her child as an altruist, while also having no willingness to be so determined herself, issues from the prohibition to help another when this damages the idea of the self. In that sense, this narrow understanding of the self allows the prohibitions to overshadow freedoms, even if at first sight it might seem just the opposite. Her answers that deferred to doctors, justified by their expertise, reveals the scope of internal prohibitions to further act on potential and free choice. Thus, such acts lead to personal disavowal of altruism and solidarity. Still, such actors think that others ought to be altruistic.

\subsubsection{Part 2: Theoretical Moral Considerations: Deontology Behind Glass}

The cases examined in Part 1 share a deferral of altruistic responsibility, in the former hobo case, from community to the state, and in the IVF case, from parent to child. In the former hobo case, the plight of those who cannot adapt to societal change by securing meaningful paid employment is to perform a slow death in public view. The homeless in Belgrade are legitimate members of society, but in full view as social outcasts. No one would say that they ought to be denied food and shelter, or for that matter, employment. But neither is there a strong, explicit articulation or practice of an obligation to provide them with such fundamental goods of human life. Participant P8 choses one twin embryo over the other for her own convenience. She does not know or apparently care what will happen to her and her husband's reproductive material that is unused by them. Thus, Participant 8 does not seek to have a child out of what is ideally understood to be parental love, with a willingness to endure personal sacrifice for the good of another. Indeed, altruism is a value she recognizes as a desirable trait for her child to have, but not a trait that she is committed to living out for herself.

Both the former hobo and IVF cases display recognitions of altruism as a virtue for others. There is no subjective obligation for individual actors. This renders altru- 
ism a form of deontology "behind glass." Anyone may value altruism as something practiced by other people and this separates moral action from moral subjects. Potential practitioners of altruism who observe such cases apathetically thus experience no obligation to perform their own duties of helping others. There is no visceral tug or heart-felt inclination to perform those duties. If the state has a duty to take care of residents but does not fulfill basic needs with adequate public shelter, this is evidence of an official failure to fulfill obligations. But not only are social duties of care deferred by the community to the state, there is no public outcry in response to state failure to fulfill its deferred obligations. This lack of indignation is what is meant by "apathy." Apathy is the result of indifference to deferred duty that is not performed and it makes sense to imagine that it would not result if solidarity were present, that is, if members of the community felt a common cause with those who are homeless.

A woman has a right to choose whether or not to continue with a pregnancy, whether it is conceived within her, or as in the case of Participant P8, in vitro. No one has what Immanuel Kant would have called a "perfect duty" to parent all children whom one is in a position to parent and able to parent. But we may have an imperfect duty to parent some of them and a perfect duty to use fair standards in choosing (Schaller 1987). ${ }^{4}$ So Participant 8 has a moral right to 'reduce' some embryos but probably not solely on the grounds of what is convenient for her personally. ${ }^{5}$

Moral consideration of the plight of vulnerable groups requires that we choose fundamental principles that will guide us to what we will recognize as kind, compassionate, or just results if those principles are applied to concrete situations. This sounds like a rigged procedure because we are choosing a moral system, not because it is right, but because we approve of the outcome. However, that may be the best we can do, insofar as moral systems have the epistemological structure of scientific theories. We choose or construct a system that provides a satisfactory account of our aspirations and experience and is capable of generating new explanations and predictions in new situations. ${ }^{6}$ For example, suppose we chose Autonomous Egoism as

\footnotetext{
${ }^{4}$ According to Kant, a perfect duty admits of no exceptions to what we are required to do in circumstances when we could perform it. An imperfect duty allows for choice or autonomy in the performance of what would otherwise be perfect duties. The example usually given is charitable donations: One has a duty to make some charitable donations, but not necessarily this one.

${ }^{5}$ In her famous argument defending a woman's right to choose whether or not to continue with a pregnancy, Judith Jarvis Thompson distinguishes between cases where a woman chooses to abort to preserve her own basic well-being versus making that choice because continuing with a pregnancy would interfere with her planned trip (Thomson 1971, 66).

${ }^{6}$ Even John Rawls referred to the theoretical nature of moral systems in his explanation of his project in A Theory of Justice:
}

I want to stress that a theory of justice is precisely that, namely a theory. It is a theory of the moral sentiments (to recall an eighteenth century title) setting out the principles governing our moral powers, or, more specifically, our sense of justice. There is a definite if limited class of facts against which conjectured principles can be checked, namely, our considered judgments in reflective equilibrium. A theory of justice is subject to the same rules of method as other theories (1971, 50-51). For discussion and further explication, see Zack 2016, 9-34 
a moral system and perceive after applying it that some autonomous acts of selfinterest are morally repugnant. That perception would work as a disconfirmation of the moral system applied.

Along similar lines, utilitarianism and virtue ethics may be judged inadequate when applied to extreme situations or conditions in which some die-quickly or slowly - when they could otherwise be saved. We might find that instead of lauding heroes who "save the greatest number" in a catastrophe, what we require morally is a principle according to which all who can be saved, fairly, are saved (Zack 2009).

There are at least two well-known formulations of Kant's categorical imperative: Act so that the maxim of your action can be willed by you to be a universal law; treat everyone, including yourself, as an end, rather than a means. The second formulation has been most influential in humanitarian plans and projects, since the end of World War II. There is a broad, albeit somewhat and sometimes vague, consensus that all human lives are intrinsically valuable, principally because, as Kant thought, they are subjectively valuable to those whose lives they are (Johnson and Cureton 2016).

The second universal intrinsic worth formulation of the categorical imperative evokes a humanitarian response when suffering occurs that is not prevented by positive law. This is the nature of moral objection to the slow death of former hobos in Belgrade and the shocking nature of reproductive autonomy without altruistic constraint or imperative. But the humanitarian objection from a deontological perspective is more than acknowledging the rightness or moral correctness of the principle that all human life (at least) is intrinsically valuable. The objection is also a focus on what happens when deontology is no longer a motivational force in people's lives. If the state is supposed (obligated) to take care of homeless people and fails to do so and members of the community accept that situation, deontology, no matter how much lip service may be given to it, has been placed behind glass. Apathy replaces dutiful action. If a prospective mother chooses altruism for her future child, but not for herself, apathy has again replaced duty (deontology).

Indeed, grim as it sounds, deontology is duty-based ethics and it may be our best moral theory as a formal expression of solidarity with others. Deontological values and principles can be taught, but we do not know as yet how to instill motivations to act from duty towards those whose suffering we know is bad, but who are not sufficiently close to or coincidental with what Kant called "the dear self:"

We cannot better serve the wishes of those who ridicule all morality as a mere chimera of human imagination over stepping itself from vanity, than by conceding to them that notions of duty must be drawn only from experience (as from indolence, people are ready to think is also the case with all other notions); for or is to prepare for them a certain triumph. I am willing to admit out of love of humanity that even most of our actions are correct, but if we look closer at them we everywhere come upon the dear self which is always prominent, and it is this they have in view and not the strict command of duty which would often require self-denial. (Kant 2014) 
In other words, according to Kant, partiality to the dear self is not a component of morality, much less a moral system. The dear self is an obstacle to morality. If members of a community are apathetic when the state does not correct the homelessness of those who lack personal relations to help them, or a parent choses altruism as a trait for her child, but not for her dear self, deontology has been obstructed. Also, according to Kant, deontology cannot be derived from social experience alone. This would certainly seem to be the case in a society dominated by the interests of dear selves. Aristotle's insistence that virtuous individuals require a virtuous state to flourish also comes to mind.

To maintain healthy optimism, we need to move from regretful longing for past types of communities that now seem more caring than the present. Instead, it is necessary to look ahead to more and better moral education and the development of communal practices of solidarity to initiate and institute new forms of social deontology. The first step is to take seriously the force of deontology to bridge the gap between what people fail to do and their recognition of what they are obligated (duty bound) to do. This is not an easy task from within a post-modern ethos that is neither strongly religious nor paternalistically statist. But taking deontology seriously is itself an imperfect duty and it can be discharged for multiple issues in multiple ways: activist organizing, inspirational speaking and speaking out, and engaging in progressive intellectual and academic discourses.

\section{References}

Batson, Daniel C. 2011. Altruism in humans. New York: Oxford University Press.

Johnson, Robert and Adam Cureton. 2016. Kant's moral philosophy. In The Stanford encyclopedia of philosophy, ed. Edward N. Zalta. http://plato.stanford.edu/archives/fall2016/entries/kantmoral/. Accessed 20 Jul 2016.

Kant, Immanuel. 2014. Second section: Transition from popular moral philosophy to the metaphysics of morals. In Fundamental principles of the metaphysics of morals. Trans. Thomas Kingsmill Abbott, e-books at University of Adelaide, paragraph 3. https://ebooks.adelaide.edu. au/k/kant/immanuel/k16prm/index.html. Accessed $20 \mathrm{Jul} 2016$.

Mitrović, Veselin. 2014. Procreative ethics of care in the process of IVF in Serbia: A culture of giving or a crisis of altruism? Temenos 1: 193-211.

. 2015a. Resilience: Detecting vulnerability in marginal groups. Disaster Prevention and Management 2: 185-200.

2015b. How Klošar became homeless upon the dissolution of Yugoslavia. In Homelessness and home. University of Oregon. http://homelessness.philosophy.uoregon.edu/narratives-ofhomelessness/. Accessed 24 Jul 2016.

- 2016. Parents' religious and secular perspectives on IVF planning in Serbia. Journal for the Study of Religions and Ideologies 43: 48-81.

Rawls, John. 1971. A theory of justice. Cambridge, MA: Harvard University Press.

Schaller, Walter E. 1987. Kant's architectonic of duties. Philosophy and Phenomenological Research 2: 299-314. 
Thomson, Judith Jarvis. 1971. A defense of abortion, Philosophy \& Public Affairs 1: 47-66. http:// www.unige.ch/lettres/baumgartner/docs/geda/Thomson_abortion.pdf. Accessed 20 Jul 2016.

Zack, Naomi. 2009. Ethics of disaster planning. In Ethics of crisis, Philosophy of Management, Special Issue, ed. Per Sandin, vol. 2, 53-64. Lanham: Rowman and Littlefield.

. 2016. Applicative justice: A pragmatic empirical approach to racial injustice. Lanham: Rowman and Littlefield.

Open Access This chapter is licensed under the terms of the Creative Commons Attribution 4.0 International License (http://creativecommons.org/licenses/by/4.0/), which permits use, sharing, adaptation, distribution and reproduction in any medium or format, as long as you give appropriate credit to the original author(s) and the source, provide a link to the Creative Commons license and indicate if changes were made.

The images or other third party material in this chapter are included in the chapter's Creative Commons license, unless indicated otherwise in a credit line to the material. If material is not included in the chapter's Creative Commons license and your intended use is not permitted by statutory regulation or exceeds the permitted use, you will need to obtain permission directly from the copyright holder. 